altered if the jury is in reality a sub rosa dispenser of justice, erring if at all in favor of the accused, for under this assumption the only difference would be defendant-prone verdicts, something beyond the reach of an acquittal procedure. But if the jury be assumed to be prosecution-prone, a group which is all too easily influenced to convict, then the strict test would appear more desirable than the majority rule if only for the reason that it will more significantly diminish the possibility of such jury behavior by removing the opportunity therefor in a greater number of cases. This assumption, furthermore, is one of the historical bases of the acquittal practice and runs throughout criminal practice, as, for example, many exclusionary rules of evidence. Which of the foregoing assumptions is empirically correct is not, however, verifiable at this time. It would thus seem wise to err on the side of mercy and follow the strict test.

In conclusion, it should be noted that the differences between the civil, majority and strict tests for weighing the evidence on a motion for judgment of acquittal are to some extent merely a matter of phraseology and of no practical import. Yet the standard chosen will at least indicate a mode of approach and as such will be crucial in many cases. Thus, the existence of three different standards would seem prima facie undesirable, for not all can be equally correct. Within the federal system, where each of these three tests is advocated by at least one circuit, it may be anticipated that the matter will soon be put to rest by the Supreme Court. ${ }^{35}$ At such time, it is to be hoped that the solution is fully in accord with enlightened criminal procedurewhich is herein submitted to require adoption of the strict test.

reasonable conclusion is possible, both tests will reach the same result. In the former situation, since the jury is in effect instructed under the strict test they will find innocence on a case sent to them under the majority rule, in which event there can be no difference. In the latter situation, the jury is presumably not instructed under the strict test, but if the one possible reasonable conclusion is only guilt (or only innocence), it is obvious that both tests will come out the same.

s Although no case is now pending, it may be inferred from a recent statement by Mr. Justice Harlan in Stickel v. United States, 76 S.Ct. 1067 (1956), that the Court will probably review federal acquittal procedure when the issue is presented in a proper case.

\title{
LANDLORD'S DUTY TO MITIGATE DAMAGES UPON TENANT'S DEFAULT
}

In Gruman v. Investors Diversified Services, Inc., ${ }^{1}$ the Supreme Court of Minnesota held that a landlord could arbitrarily refuse to consent to a sublease to a suitable subtenant secured by the tenant in an attempt to mitigate damages on a defaulted lease. The tenant had agreed not to "assign this lease nor underlet said premises, or any part thereof, without the consent of the

${ }^{2} 247$ Minn. 502, 78 N.W.2d 377 (1956). 
Lessor in writing." ${ }^{\prime 2}$ The parties of the action stipulated that the proposed subtenant, the Postmaster General of the United States, was "in all respects a highly satisfactory, desirable, and suitable subtenant. . . ."3 Although no case involving a similar fact situation had previously been decided in Minnesota, the court thought its decision dictated by a "majority rule" that:

[I]n a lease such as this the lessor does not have the duty of mitigating damages; [and] may arbitrarily refuse to accept a subtenant suitable and otherwise responsible....4

However, only one of the twenty-five cases cited is authoritative for the proposition that if the tenant has agreed not to sublet without the landlord's consent, a landlord may arbitrarily refuse to consent to a sublease to a suitable subtenant secured by the defaulting tenant. ${ }^{5}$ The remaining cases hold only that a landlord need not seek out or let to a new tenant if the defaulting tenant vacates or abandons the premises. ${ }^{6}$

The Gruman opinion confuses two situations. In the first, that represented by the Gruman facts, the tenant locates a suitable subtenant and requests the landlord's consent to a sublease. The issue here is whether or not the landlord has the duty to mitigate damages by consenting to the sublease, even though the tenant has contracted, by a no-sublease clause, to give the landlord complete discretion to reject any individual subtenant. In considering this issue in the Gruman case the court failed to distinguish a second situation where the tenant abandons before the end of the term without locating a subtenant. Here the issue is whether or not the landlord has the duty to mitigate damages by seeking out and letting to a new tenant. ${ }^{7}$ The issue is not significantly altered if the new tenant is procured by the original tenant and a second lease, rather than a sublease, is proposed. In either variation of this second situation it may be conceded that the landiord is not required to mitigate damages by letting directly to the new tenant because he may thereby waive his right to any damages. ${ }^{8}$

\footnotetext{
${ }^{2}$ Tbid., at 504 and $378 . \quad{ }^{3} \mathrm{Tbid}$., at 505 and $379 . \quad$ Ibid., at 505-6 and 379.
}

'Friedman v. Thomas J. Fisher \& Co., 88 A.2d 321 (Mun.App.D.C., 1952), holds that a landlord may arbitrarily refuse his consent for subletting to a party proffered by the tenant without reducing the tenant's liability in an action for rentals. See Manley v. Kellar, 47 Del. 511, 94 A.2d 219 (Super.Ct., 1952); Zucker v. Dehn, 128 N.J.L. 435, 26 A.2d 564 (1942).

${ }^{\circ}$ Cases cited in Gruman v. Diversified Services, Inc., 247 Minn. 502, 506, 78 N.W.2d 377, 379-80 (1956). One of these cases, Williams v. Aeroland Oil Co., 155 Fla. 114, 20 So.2d 346 (1944), holds only that the landlord cannot recover rentals not yet due.

'The presence or absence of a no-sublease clause is immaterial in this situation for, absent the original tenant's acquiescence, any new tenant would hold directly under the landlord and would not be a subtenant.

${ }^{8}$ Consult discussion at 569 infra. Compare the rule in a small minority of jurisdictions which apply the contract rule and require the landlord to seek a new tenant. Friedman v. Colonial Oil Co., 236 Iowa 140, 18 N.W.2d 196 (1945); Maremont v. Axe, 135 Kan. 368, 10 P.2d 836 (1932); see Galvin v. Lovell, 257 Wis. 82, 42 N.W.2d 456 (1950). 
The question presented by the Gruman facts, where the original tenant requests the landlord's consent to a sublease, is less obvious. The Gruman case presents squarely a conflict between a policy favoring the sanctity of the contractual no-sublease clause and policies favoring mitigation of damages and the free alienability of property interests. The general function of expectation damages in contract law is to place the injured party in as good a position as he would have been had the contract been fully performed; ${ }^{9}$ the purpose of the rule requiring mitigation of damages is to obviate compensation by the defendant for losses which the plaintiff might reasonably have avoided. ${ }^{10}$ As a lease is at least partially a contractual relationship, it would seem that the mitigation rule should apply to the defaulting tenant's liability for unpaid rent unless there are factors peculiar to the lease-contract compelling a contrary result. The Gruman court pointed to three factors supposedly rendering the mitigation of damages rule inapplicable where the defaulting tenant requests the landlord's consent to a sublease; each factor will be seen to be inapplicable if the basic distinction, outlined above, between a consent to sublease and an original lease to a new tenant is borne in mind.

First, the Gruman court argued that one of a landlord's reasons for entering into non-cancellable leases is to eliminate the burden of continually seeking out new tenants. This argument is irrelevant, however, for in the Gruman situation the defaulting tenant has procured the putative subtenant, and to require the landlord to mitigate damages by consenting to the sublease would impose no such burden.

Second, the Gruman court feared that the property relationship between the landlord and the defaulting tenant might be jeopardized if the landlord were forced to seek out and let to a new tenant. This could result because the landlord's actions-inconsistent with the continued existence of the tenant's estate $^{11}$-might be taken as an acceptance of the tenant's abandonment, thereby terminating the landlord-tenant relationship and releasing the defaulting tenant from further liability for rentals. ${ }^{12}$ This would not be the case

- Sharp, Promissory Liability, 7 U. of Chi. L. Rev. 1, 20 (1939); Fuller and Perdue, The Reliance Interest in Contract Damages, 46 Yale L. J. 52, 54 (1936).

${ }^{10} 5$ Corbin, Contracts $\$ 1039$ (1951).

11 "[A surrender by operation of law], as said by Parke, B., in Lyon v. Reed, 13 M. \& W. 285,306 , can only take place 'where the owner of a particular estate has been a party to some act, the validity of which he is by law afterwards estopped from disputing, and which would not be valid if his particular estate had continued to exist.' Such would be the case of a lessor taking unqualified possession of demised premises, and dealing with them in a way wholly inconsistent with the continuance of an already existing and unexpired term. In such a case, as against the lessor, the law, upon the principle of estoppel, implies a mutual agreement between him and his lessee, whereby the possession of the premises has been abandoned by the latter, and resumed by the former, in pursuance of such agreement." Gruman v. Investors Diversified Services, Inc., 247 Minn. 502, 508, 78 N.W.2d 377, 381 (1956) (brackets supplied by the court), quoting Nelson v. Thompson, 23 Minn. 508, 512 (1877).

${ }^{12}$ Consult Tiffany, Real Property $\$ \$ 902,962$ (3d ed., 1939). 
if the landlord acts as the defaulting tenant's agent in securing a subtenant; ${ }^{13}$ but, since the courts do not agree upon the time when the agency relationship is established, if a landlord re-rents he acts at the peril of releasing the defaulting tenant from further liability for rentals. ${ }^{14}$ When, as in the Gruman case, the defaulting tenant negotiates directly with the new tenant, however, involving the landlord only to obtain his permission for the proposed sublease, there is no act which could conceivably be regarded as inconsistent with the continued existence of the tenant's estate. In such a situation the landlord not only may continue to look solely to the original tenant for his rentals but also has the added security of the subtenant's liability to the tenant.

Equally unpersuasive is the court's final argument that the lease clause requiring the landlord's permission to sublet or assign entitled the landlord to an unrestricted personal choice of tenants. It is true that the landlord, because of his legal responsibility for the condition of the premises, ${ }^{15}$ should not be denied the protection in choice of occupants he has sought by requiring permission to sublet. ${ }^{16}$ But this is not to say that he should be given the same right of tenant selection as if he were acting for himself. Even in employment contracts, where the personal relationship plays a much greater role, courts have imposed a duty on wrongfully discharged employees to accept similar employment if available, or forfeit the right to damages for the amount which could have been earned. ${ }^{17}$ Similarly, the landlord should be held at least to a reasonable commercial standard in exercising his discretionary power to reject a proposed subtenant. Application of this standard is not unprecedented in the law of landlord and tenant. The standard has been accepted and defined in cases in which the landlord re-entered under a provision of the lease per-

\footnotetext{
${ }^{13}$ Ogden v. Rowe, 3 E. D. Smith 312 (N.Y.C.P., 1854) ; Tiffany, Landlord and Tenant $\$ \$ 1340,1341$ (1920).

${ }^{14}$ In McGrath v. Shalett, 114 Conn. 622, 159 Atl. 633 (1932), after the tenant had vacated, the landlord entered, materially altered the premises, and relet to a third party without notifying the original tenant. The court, allowing the landlord to recover the difference in rentals from the original tenant, said that the landlord should not be penalized for attempting to minimize damages or for attempting to keep his property from deteriorating. But in Gray v. Kaufman Dairy \& Ice Cream Co., 162 N.Y. 388, 56 N.E. 903 (1900), although the landlord refused to accept the keys and notified the vacated tenant that he was reletting the premises on the tenant's account, the court held that the act of the landlord in reletting under such circumstances operated as acceptance of the tenant's offer to surrender.

${ }^{15}$ Altz v. Leiberson, 233 N.Y. 16, 134 N.E. 703 (1922); Rest., Torts $\$ \$ 360,361$ (1934).

${ }^{16}$ As a general rule, absent a clause in the lease requiring the landlord's permission to sublet, a tenant may rent to whomever he chooses. Syracuse Savings Bank v. D'Elia, 56 N.Y.S.2d 800 (N.Y. Mun. Ct., 1945); Leslie v. Sherman, 157 Kan. 157, 139 P.2d 133 (1943) ; Granite Trust Bldg. Corp. v. Great Atlantic \& Pacific Tea Co., 36 F.Supp. 77 (D. Mass., 1940).

${ }^{17}$ Schisler v. Perfection Milker Co., 193 Minn. 160, 258 N.W. 17 (1934) ; Flickema v. Henry Kraker Co., 252 Mich. 406, 233 N.W. 362 (1930); McClelland v. Climax Hosiery Mills, 252 N.Y. 347,169 N.E. 605 (1930).
} 
mitting him to do so after the tenant abandoned the premises. ${ }^{18}$ In such cases, although the landlord is not required to relet the premises for a longer period than the term of the original lease, ${ }^{10}$ it may be his duty to let them for a shorter period. ${ }^{20}$ The landlord is not required to relet them for a different purpose if he reasonably believes that such use will damage the premises. ${ }^{21}$ Although the landlord is not required to alter the premises to secure a new tenant, he must put the premises in a condition to be occupied. ${ }^{22}$ Courts have gone so far as to hold that the landlord is not acting for himself in the reletting, and mere opinion, unsupported by reason, would be insufficient ground for rejecting a tenant. ${ }^{23}$ The standard has also been defined where the lease forbids subletting without the landlord's consent but provides that such consent will not be unreasonably withheld. One such case held it unreasonable for a landlord, whose place of business was within two blocks of the leased premises, to refuse to accept a proposed subtenant engaged in the same type of business. ${ }^{24}$

The factors to which the Gruman court pointed are, therefore, not controlling under the circumstances involved there, where the defaulting tenant requests the landlord's consent to a sublease. The general contracts rule requiring mitigation of damages should, therefore, be applicable to the Gruman situation even though, under present law, that rule clearly does not require the landlord to seek out or let directly to a new tenant.

A proposed solution would be to give the landlord the option of consenting to a suitable subtenant or of crediting the defaulting tenant, in any action against him for rentals on the leasehold, with the amount which would have been paid by the subtenant had he been accepted. ${ }^{25}$ The tenant should be

${ }^{18}$ Monger v. Luterbok, 195 N.C. 274, 142 S.E. 12 (1928); Greenstine v. Srere, 222 Mich. 25, 192 N.W. 676 (1923).

${ }^{10}$ Rohinson Seed \& Plant Co. v. Hexter \& Kramer, 167 S.W. 749 (Tex. Civ. App., 1914).

${ }^{\circ}$ Leo v. Pearce Stores Co., 57 F.2d 340 (E.D. Mich., 1932).

${ }^{\mathrm{M}}$ Allen v. Saunders, 6 Neb. 436 (1877) ; Consumers Market House Co., v. Powers, 192 Ill.App. 89 (1915).

"Woodbury v. Sparrell Print, 198 Mass. 1, 84 N.E. 441 (1908).

${ }^{2}$ Fitch v. Armour, 14 N.Y.Supp. 319 (Super. Ct., 1891).

${ }^{24}$ The court pointed out that if the landlord had desired to prevent subletting of the premises to a business competitor he should have so stated in the lease. Since he had not done this his objection to the subtenant was both arbitrary and unwarranted. Edelman v. F. W. Woolworth Co., 252 Ill.App. 142 (1929).

$\approx$ The same result should be reached even if the lease specifically states that the landlord can reject a proffered tenant in his absolute discretion without crediting the lessee with the rentals which would otherwise have been received. If such a clause were given effect it would be tantamount to allowing a party to contract out of his duty to mitigate damages. The reasons for making the landlord credit the rentals if he does not accept a suitable tenant under the type of lease involved in the Gruman case apply with equal force to a lease which purports to make this obligation subject to the landlord's absolute discretion.

The courts refuse to enforce penalty provisions because "justice requires nothing more than compensation measured by the amount of the harm suffered." 5 Corbin, Contracts 
required not only to prove that the proposed subtenant meets reasonable commercial standards of credit and reputation but also to disprove any particular allegations that the landlord's interests would be damaged by the proposed subtenancy. This solution allows the landlord to protect his legitimate business interests and to meet the legal requirements of care in tenant selection, for he can still, in the exercise of reasonable discretion, reject a truly undesirable subtenant. At the same time it relieves the tenant from unnecessary hardship and permits more efficient utilization of the community's economic resources.

$\$ 1057$, at 280 (1951). Similarly, a clause which exempts a party from his obligation to avoid damages should not be enforced since justice does not require compensation for harm needlessly suffered.

\section{COLLECTION CAPERS: LIABILITY FOR DEBT COLLECTION PRACTICES}

The legality of widespread debt collection practices has been a fertile and ever-increasing source of controversy. The creditor, or more commonly a collection agency, may continually hound the debtor with threats ranging from the institution of legal proceedings to the economic and social pressure afforded by exposure of the debtor's financial circumstances to others. Moreover, as illustrated by several recent cases, these threats are in many instances carried out. ${ }^{1}$ This comment will discuss the existing legal restrictions on such collection activity with the aim of delineating the boundaries of permissible conduct.

\section{Unauthorized Practice of Law}

The creditor seeking payment will often enlist the services of a commercial collection agency. Conflict between certain practices followed by these agencies and the efforts of the bar to eliminate lay competition forms a focal point for present legal dispute. ${ }^{2}$ When such conflict exists, the sanction may be formidable. The layman who is held to be engaged in the unauthorized prac-

\footnotetext{
${ }^{1}$ For descriptions of collection activity consult, e.g., Housh v. Peth, 165 Ohio St. 35, 133 N.E.2d 340 (1956), noted in 7 West. Res. L. Rev. 461 (1956), and 2 Wayne L. Rev. 240 (1956); Duty v. General Finance Co., 154 Tex. 16, 273 S.W.2d 64 (1954). Consult also Butterfield, Collection Agencies and the Courts, 5 Law \& Contemp. Prob. 47 (1938) ; Birkhead, Collection Tactics of Illegal Lenders, 8 Law \& Contemp. Prob. 78 (1941); Otterbourg, Collection Agency Activities: The Problem from the Standpoint of the Bar, 5 Law \& Contemp. Prob. 35 (1938) ; Nugent, Devices for Liquidating Small Claims in Detroit, 2 Law \& Contemp. Prob. 259 (1935) ; Harris, Improper Methods of Collecting Debts, 58 Com. L. J. 5 (1953).

${ }^{2}$ Consult Johnstone, The Unauthorized Practice Controversy, A Struggle Among Power Groups, 4 Kan. L. Rev. 1 (1955), for an exhaustive treatment. Closely analogous to activities of the American Bar Association in this regard are the activities of the American Medical Association, discussed in The American Medical Association: Power, Purpose and Policies in Organized Medicine, 63 Yale L. J. 938 (1954).
} 